\title{
Decision Support System To Choose The Best Social Media Platform For Product Marketing Using Topsis Method
}

\author{
Dwi Andini Putri ${ }^{1}$, Enok Tuti Alawiah ${ }^{2}$;: \\ 1.2Universitas Bina Sarana Informatika \\ dwi.dwd@bsi.ac.id,enok.etw@bsi.ac.id
}

\begin{abstract}
Currently, many content creators use social media to conduct product reviews or testimonials. This often attracts followers to make purchases of the same product. Marketing of products with social media is mostly done by the industry to attract buyers. However, in-depth research is needed to analyze which social media is most appropriate to use to market their products. This study uses the TOPSIS method, which is a multicriteria selection method that uses a positive and negative ideal solution distance approach to obtain a valid final preference value. The results showed that as many as 0.31 social media youtube, 0.24 for social media tiktok, 0.20 for social media instagram and 0.11 for social media facebook. The results of the study can be used by policy makers to decide the selection of the right social media for marketing their products.
\end{abstract}

Keywords: TOPSIS, Decision Support System, Social Media

\section{Introduction}

In 2018 the number of internet and social media users reached 4 billion or equivalent to $52.96 \%$ of the total world population of 7.59 billion people [1]. This makes social media the right target for product marketing. There are many content creators who create content to market a product through social media. Marketing using social media is believed to be able to foster customer trust so that many products are sold in the market. The findings show that the most widely used social media for product marketing are Instagram $78 \%$, Youtube 58\%, Facebook 31\%, Whatsapp 20\%, Line 18\%, Path 7\% and Twitter $2 \%$. Social media has greatly helped students and even the public and entrepreneurs in promoting products. With this, it is proven that many social media users provide good benefits in terms of product marketing. With the advancement of technology, even with the existence of social media, people, especially entrepreneurs, can reach potential buyers easily [2].

Topsis method can help to determine media decisions the best social media as a place to do promotions. Of the 150 questionnaires that have been processed, the results What is obtained is that TikTok social media is the best means of promotion, with high value obtained is 0.424 [3]. Based on the test results, it can be concluded that the purchasing decision variable $(\mathrm{Y})$ is influenced by the trust variable $(\mathrm{X} 1)$ of 0.285 , security $(\mathrm{X} 2)$ of 0.217 and information quality (X3) of 0.334 . This study shows the influence of trust, security and quality of information by $57.9 \%$ on the purchasing decisions of online shop users of the Instragram social network. Based on the F test, it can be seen that trust, ease and quality of information have a simultaneous effect on purchasing decisions. Based on the $t$ test, it can be seen that the trust, ease and quality of information partially affect the purchase decision, while the quality of information has a dominant effect on purchasing decisions [4]. Promotion with Social Media has a positive and significant impact on the Purchase Decision of Ortuseight Sports Shoes. This positive influence shows that effective promotion with social media will further increase the Ortuseight Sports Shoes Purchase Decision in the Tanjung Morawa Community [5]. 
Currently, many industries and manufacturers use social" mede marketing their products. Therefore, this study aims to help analyze decisions on thoosing the right social media for marketing a product. This research was "conducted using the TOPSIS method because TOPSIS can calculate a multi-criteria asseissment that helps the decision-making process.

\section{Research Methodology}

\subsection{Decision Support System}

A decision support system is an interactive system that uses a person's intellectual resources and is combined with a computer to make certain decisions [6]. Decision support system is a system used to support managerial decision makers to solve unstructured decision problems [7]. Decision support system (DSS) is one of the tools that can be used for the decision-making process for decision makers. The decisions offered by the decision support system tend to be fast and quantitatively the best choice based on the level of importance/weight of the criteria given by the management as the decision maker. With the help of a decision support system, complex decision making can be shortened [8].

\subsection{TOPIS Method}

The TOPSIS method was first formulated by Hwang and Yoon. TOPSIS is a simple and efficient multi-criteria method to solve problems with various alternatives [6]. TOPSIS method is a method that is widely used for the decision-making process so that policies will be selected based on the best choice and TOPSIS also has a simple and easyto-understand concept [9]. The Technique for Order Preference by Similarity to Ideal Solution (TOPSIS) is a multi-criteria decision-making method based on the concept that the best alternative not only has the shortest distance from the positive ideal solution but also has the longest distance from the negative ideal solution [10].

\subsection{Social Media}

Social media is used as a means to interact, communicate, and build networks through online communication media. Basically media social media is the latest development of new internet-based web technologies, which make it easier for everyone to communicate, participate, share and form am network online, so that it can disseminate their own content [11]. Social media can be used to carry out various two-way activities in various forms of exchange, collaboration, and getting to know each other in the form of writing, visuals, and audio-visuals[12]. Social media is a way for consumers to share text, images, audio, and information with each other and with company or vice versa [13].

\section{Result and Discussion}

\subsection{Research and Population}

The research population comes from respondents who are active in using social media. The questionnaire used in this study was a closed question with a limited number of statements and answers. The questions on the closed questionnaire are based on studies from various research-related sources. The questions used in the questionnaire were measured using the following five Likert scales:

Table 1. likert scale

\begin{tabular}{|l|c|c|}
\hline \multirow{2}{*}{ Answer } & \multicolumn{2}{|c|}{ Score } \\
\cline { 2 - 3 } & Positives & Negative \\
\hline Always & 5 & 1 \\
\hline Often & 4 & 2 \\
\hline Sometimes & 3 & 3 \\
\hline
\end{tabular}




\begin{tabular}{|l|c|c|}
\hline \multirow{2}{*}{ Answer } & \multicolumn{2}{|c|}{ Score } \\
\cline { 2 - 3 } & Positives & Negative \\
\hline Almost never & 2 & 4 \\
\hline Never & 1 & 5 \\
\hline
\end{tabular}

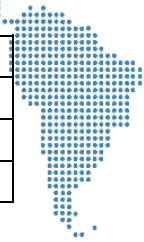

\subsection{Research Metodhs}

The following is a research step with the TOPSIS method:

a) Normalized Decision Matrix Analysis. Making a normalized decision matrix is a step in the TOPSIS method that requires a performance rating of each alternative Ai on each normalized Ci criteria.

b) Calculating normalized matrix ( $\mathrm{R})$.

c) Calculating weighted normalized matrix ( $\mathrm{Y})$.

d) Calculating positive $(\mathrm{A}+)$ and negative $(\mathrm{A}-)$ ideal solutions.

e) Calculate the distance of the ideal negative solution (D-) and the positive ideal solution $(+)$

f) Calculating the preference value for each alternative offered.

\subsection{Result}

The results of the study to determine the weight of the criteria are:

a) A large number of social media users (C1)

b) Popular (C2)

c) Social media platforms according to business characteristics (C3)

d) Availability across all application platforms (C4)

The following is a table of research criteria:

Table 2. likert scale

\begin{tabular}{|l|l|}
\hline Social media & criteria \\
\hline Youtube & A1 \\
\hline Tiktok & A2 \\
\hline Facebook & A3 \\
\hline Instagram & A4 \\
\hline
\end{tabular}

Source: Research Result

Table 3. Normalized Decision Matrix

\begin{tabular}{|l|l|l|l|l|}
\hline Criteria & C1 & C2 & C3 & C4 \\
\hline A1 & 5 & 5 & 4 & 5 \\
\hline A2 & 5 & 4 & 4 & 5 \\
\hline A3 & 4 & 3 & 3 & 4 \\
\hline A4 & 5 & 4 & 4 & 4 \\
\hline
\end{tabular}

Table 4. Criteria Weighted Score

\begin{tabular}{|l|l|l|l|}
\hline C1 & C2 & C3 & C4 \\
\hline 5 & 4 & 4 & 5 \\
\hline
\end{tabular}

Table 5. Normalized Value

\begin{tabular}{|l|l|l|l|l|}
\hline Criteria & C1 & C2 & C3 & C4 \\
\hline A1 & 5 & 5 & 4 & 5 \\
\hline A2 & 5 & 4 & 4 & 5 \\
\hline A3 & 4 & 3 & 3 & 4 \\
\hline A4 & 5 & 4 & 4 & 4 \\
\hline Result & 91 & 66 & 57 & 82 \\
\hline Score & 9,5 & 8,1 & 7,5 & 9,0 \\
\hline
\end{tabular}


Table 6. Normalized Matrix C1

\begin{tabular}{|c|c|c|c|}
\hline Criteria & C1 & Result & Score \\
\hline A1 & 5 & 9,5 & 0,52 \\
\hline $\mathrm{A} 2$ & 5 & 9,5 & 0,52 \\
\hline $\mathrm{A} 3$ & 4 & 9,5 & 0,42 \\
\hline $\mathrm{A} 4$ & 5 & 9,5 & 0,52 \\
\hline
\end{tabular}

Table 7. Normalized Matrix C2

\begin{tabular}{|l|l|l|l|}
\hline Criteria & C1 & Result & Score \\
\hline A1 & 5 & 8,1 & 0,61 \\
\hline A2 & 4 & 8,1 & 0,49 \\
\hline A3 & 3 & 8,1 & 0,37 \\
\hline A4 & 4 & 8,1 & 0,49 \\
\hline
\end{tabular}

Table 8. Normalized Matrix C3

\begin{tabular}{|l|l|l|l|}
\hline Criteria & C1 & Result & Score \\
\hline A1 & 4 & 7,5 & 0,53 \\
\hline A2 & 4 & 7,5 & 0,53 \\
\hline A3 & 3 & 7,5 & 0,40 \\
\hline A4 & 4 & 7,5 & 0,53 \\
\hline
\end{tabular}

Table 9. Normalized Matrix C4

\begin{tabular}{|l|l|l|l|}
\hline Criteria & C1 & Result & Score \\
\hline A1 & 5 & 9,0 & 0,55 \\
\hline A2 & 5 & 9,0 & 0,55 \\
\hline A3 & 4 & 9,0 & 0,43 \\
\hline A4 & 4 & 9,0 & 0,43 \\
\hline
\end{tabular}

Table 10. Normalized Data

\begin{tabular}{|l|l|l|l|l|}
\hline Criteria & C1 & C2 & C3 & C4 \\
\hline A1 & 0,52 & 0,61 & 0,53 & 0,55 \\
\hline A2 & 0,52 & 0,49 & 0,53 & 0,55 \\
\hline A3 & 0,42 & 0,37 & 0,40 & 0,43 \\
\hline A4 & 0,52 & 0,49 & 0,53 & 0,43 \\
\hline
\end{tabular}

Table 11. Weighted Normalized Matrix

\begin{tabular}{|l|l|l|l|l|}
\hline Criteria & C1 & C2 & C3 & C4 \\
\hline A1 & 2,6 & 2,44 & 2,12 & 2,75 \\
\hline A2 & 2,6 & 1,96 & 2,12 & 2,75 \\
\hline A3 & 2,1 & 1,48 & 1,60 & 2,15 \\
\hline A4 & 2,6 & 1,96 & 2,12 & 2,15 \\
\hline
\end{tabular}

Table 12. Value of Positive and negative ideal solutions

\begin{tabular}{|l|l|l|l|l|}
\hline Criteria & C1 & C2 & C3 & C4 \\
\hline A1 & 2,6 & 2,44 & 2,12 & 2,75 \\
\hline A2 & 2,6 & 1,96 & 2,12 & 2,75 \\
\hline A3 & 2,1 & 1,48 & 1,60 & 2,15 \\
\hline A4 & 2,6 & 1,96 & 2,12 & 2,15 \\
\hline Min & 2,1 & 1,48 & 1,60 & 2,15 \\
\hline Maks & 2,6 & 2,44 & 2,12 & 2,75 \\
\hline
\end{tabular}


Table 13. Weighted Normalized Matikn

\begin{tabular}{|c|c|c|}
\hline Criteria & D+ & D- \\
\hline C1 & 6,02 & 2,71 \\
\hline $\mathrm{C} 2$ & 6.26 & 2,02 \\
\hline $\mathrm{C} 3$ & 7,55 & 1,004 \\
\hline $\mathrm{C} 4$ & 6,62 & 1,66 \\
\hline
\end{tabular}

Table 14. Final Preference Value

\begin{tabular}{|l|l|r|}
\hline Criteria & C1 & C2 \\
\hline C1 & $(2,71) /(2,71+6,02)$ & 0.31 \\
\hline C2 & $(2,02) /(2,02+6.26)$ & 0.24 \\
\hline C3 & $(1,004) /(1,004+7,55)$ & 0.11 \\
\hline C4 & $(1,66) /(1,66+662)$ & 0.20 \\
\hline
\end{tabular}

Based on the research that has been done, it is found that the final preference values are $0.31,0.24,0.20$ and 0.11 . if sorted by type of social media that allows it to be used for marketing media, the first order of marketing should be done on social media Youtube, Tiktok, Instagram and Facebook. The results of the study are based on the responses of active social media users who have made purchase transactions because of reviews of content creators who use social media to market goods. The results of this study can be a reference for producers or sellers to market their products using social media.

\section{Conclusion}

Product marketing using social media is becoming a new trend along with the high growth of social media users. Social media users often use social media as a platform to create product reviews or product testimonials. This often attracts followers to make purchases of the same product. Therefore, industry players, producers and sellers see this as an attractive market segmentation. However, it is necessary to choose the right social media so that product sales are right on target according to needs. This study aims to support the decisions of industrial actors, producers and sellers to decide which social media to use as product marketing media. The research was conducted using the TOPSIS method, which is a method that uses alternative criteria to formulate the results of the selection.

The analysis carried out on four social media namely Youtube, Tiktok, Facebook and Instagram resulted final preference values are $0.31,0.24,0.20$ and 0.11 . if sorted, marketing should be done on social media youtube, tiktok, instagram and finally facebook.

\section{References}

[1] R. Rusliyawati, D. Damayanti, and S. N. Prawira, "Implementasi Metode Saw Dalam Sistem Pendukung Keputusan Pemilihan Model Social Customer Relationship Management," Edutic - Sci. J. Informatics Educ., vol. 7, no. 1, pp. 12-19, 2020, doi: 10.21107/edutic.v7i1.8571.

[2] A. O. Siagian, R. Martiwi, and N. Indra, "Kemajuan Pemasaran Produk Dalam Memanfaatkan Media Sosial Di Era Digital," J. Pemasar. Kompetitif, vol. 3, no. 3, p. 44, 2020, doi: 10.32493/jpkpk.v3i3.4497.

[3] Y. E. Kiswati, "PENGAMBILAN KEPUTUSAN MEDIA PEMASARAN DIGITAL TERBAIK," no. 2020, pp. 1-6, 2021.

[4] S. Nawangsari and Y. Kamayanti, "Pengaruh Kepercayaan, Kemudahan, Dan Kualitas Informasi Terhadap Keputusan Pembelian Melalui Media Sosial Instagram," Konf. Nas. Sist. Inf. 2018 STMIK Atma Luhur Pangkalpinang, vol. 89, pp. 8-9, 2018. 


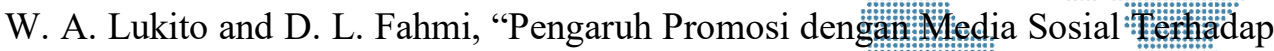

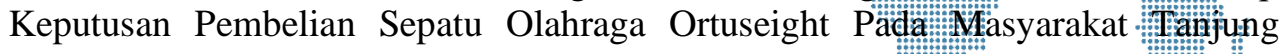
Morawa," J. Econ. Account., vol. 1, no. 2, pp. 90-95, 2020

[6] A. A. Chamid, "Prioritas Kondisi Rumah," J. Simetris, vơm '7, no. 2, pp. 537-544, 2016.

[7] C. Surya, "Penilaian Kinerja Dosen Menggunakan Metode TOPSIS (Studi Kasus : Amik Mitra Gama)," J. RESTI (Rekayasa Sist. dan Teknol. Informasi), vol. 2, no. 1, pp. 322-329, 2018, doi: 10.29207/resti.v2i1.119.

[8] P. A. W. Santiary, P. I. Ciptayani, N. G. A. P. H. Saptarini, and I. K. Swardika, "Jurnal Pengertian Topsis," vol. 5, no. 5, pp. 621-628, 2018, doi: 10.25126/jtiik2018551120.

[9] E. T. Alawiah and D. A. Putri, "Implementasi Metode TOPSIS Pada Penerima Bantuan Sosial Akibat Covid19 di Desa Kota Batu Ciomas Bogor," J. Sains Komput. Inform., vol. 5, no. 1, pp. 72-82, 2021, [Online]. Available: https://tunasbangsa.ac.id/ejurnal/index.php/jsakti/article/view/299.

[10] Sefrika, "Sistem Pendukung Keputusan Penggunaan Uang Elektronik Untuk Belanja Retail Dengan Metode TOPSIS," (Indonesian J. Comput. Inf. Technol., vol. 6, no. November 2020, pp. 25-30, 2021.

[11] yuni Fitriani, "Analisis Pemanfaatan Berbagai Media Sosial sebagai Sarana Penyebaran Informasi bagi Masyarakat," Paradig. - J. Komput. dan Inform., vol. 19, no. 2, p. 152, 2017, [Online]. Available: http://ejournal.bsi.ac.id/ejurnal/index.php/paradigma/article/view/2120.

[12] R. Anizir; Wahyuni, "Pengaruh Social Media Marketing Terhadap Brand Image Perguruan Tinggi Swasta Di Kota Serang,” J. Sains Manaj., vol. 3, no. 2, p. 0, 2017, [Online]. Available: http://ejurnal.lppmunsera.org/index.php/SM/article/view/25.

[13] S. A. Refiani and A. Mustikasari, "Analisis Pengaruh Sosial Media Marketing Melalui Instagram Terhadap Keputusan Pembelian Studi Pada This! By Alifah Ratu Tahun 2020," eProceedings Appl. Sci., vol. 6, no. 2, pp. 2753-2758, 2020.

\section{Authors}

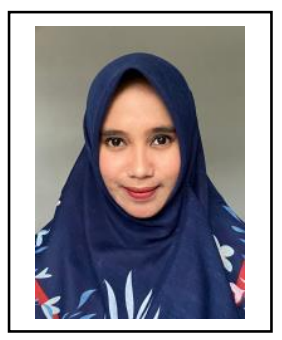

\section{1nd Author}

Dwi Andini Putri

Lecturer of Universitas Bina Sarana Informatika, Indonesia

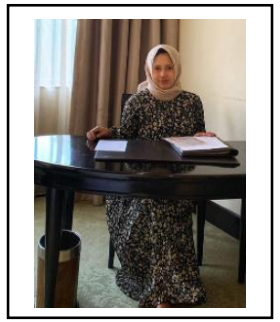

\section{2nd Author}

Enok Tuti Alawiah

Lecturer of Universitas Bina Sarana Informatika, Indonesia 